\title{
KIR2DS1 wt Allele
}

National Cancer Institute

\section{Source}

National Cancer Institute. KIR2DS1 wt Allele. NCI Thesaurus. Code C106093.

Human KIR2DS1 wild-type allele is located in the vicinity of 19q13.4 and is approximately $14 \mathrm{~kb}$ in length. This allele, which encodes killer cell immunog lobulin-like receptor 2DS1 protein, is involved in the modulation of NK cell function. 